\title{
Sulfur-containing species in a snow pit in the Lambert Glacier basin, East Antarctica
}

\author{
SunJunying, Ren Jianen, Qin Dahe, Wang Xiaoxiang \\ Laboratory of Ice Core and Cold Regions Environment, Lanzhou Institute of Glaciology and Geocryology, \\ Chinese Academy of Sciences, Lanzhou, Gansu 730000, China
}

\begin{abstract}
A $2.7 \mathrm{~m}$ snow pit was sampled in the Lambert Glacier basin, about $650 \mathrm{~km}$ from the coast. Concentrations of methanesulfonic acid (MSA) and non-sea-salt $\mathrm{SO}_{4}{ }^{2-}\left(\mathrm{nssSO}_{4}{ }^{2-}\right)$ show distinct variation with depth in the snow pit. The seasonal variation of MSA is used to date the snow-pit samples. MSA concentration is in the range 1.9$22.0 \mu \mathrm{g} \mathrm{kg}^{-1}$ with a mean of $7.0 \mu \mathrm{g} \mathrm{kg}^{-1}$. The mean $\mathrm{nsSSO}_{4}{ }^{2-}$ concentration is $41.5 \mu \mathrm{g} \mathrm{kg}^{-1}$ with a range of $0-87 \mu \mathrm{g} \mathrm{kg}^{-1}$. The nssSO $_{4}{ }^{2-}$ concentration was calculated by subtracting the sea-salt sulfate contribution using $\mathrm{Na}^{+}$as a conservative tracer. The nssSO ${ }_{4}^{2-}$ contributes about $80 \%$ of the total sulfate in the snow pit. The mean mass ratio of MSA to $\mathrm{nssSO}_{4}{ }^{2-}, 0.176$, is much higher than that measured in the low to mid-latitudes, but is very close to the ratio in snow at the South Pole. El Chichon and Hudson volcanic eruptions do not significantly perturb the nssSO ${ }_{4}^{2-}$ concentrations at this site. MSA concentrations are anticorrelated with sea-ice area for the South Indian Ocean sector between $40^{\circ}$ and $90^{\circ} \mathrm{E}$, suggesting enhanced MSA production accompanying low sea-ice coverage.
\end{abstract}

\section{INTRODUCTION}

Sulfur-containing compounds in the troposphere play an important role in atmospheric acid-base chemistry and in the formation and growth of aerosol particles, and may thus affect the climate through the potential interaction of such aerosols with incoming solar radiation (Charlson and others, 1987). Studies conducted in the past 20 years indicate that most of the sulfate aerosol originates from chemical reactions of sulfur gases discharged into the atmosphere. Sulfur gases have various sources, such as the marine and terrestrial biosphere, volcanoes, biomass burning and anthropogenic emissions. Present-day anthropogenic emissions are thought to represent around $84 \%$ and $40 \%$ of the sulfur budget in the Northern and Southern Hemispheres, respectively (Bates and others, 1992). However, in the region south of $50^{\circ} \mathrm{S},>90 \%$ of the sulfur budget is derived from the marine biosphere, mainly in the form of dimethylsulfide (DMS) (Bates and others, 1992). In the atmosphere, DMS is oxidized via two routes by the hydroxyl radical: H-abstraction and $\mathrm{OH}$-addition (Saltzman, 1995). Methanesulfonic acid (MSA) and $\mathrm{SO}_{2}$ (further oxidized to $\mathrm{SO}_{4}{ }^{2-}$ ) are the two major oxidation products. Unlike $\mathrm{SO}_{4}{ }^{2-}$, DMS oxidation is the only known source of atmospheric MSA. Thus, the MSA record in snow and ice cores has been used to investigate the variability of marine DMS emissions in the past (Saigne and Legrand, 1987; Legrand and Feniet-Saigne, 1991; Pasteur and others, 1995). However, in order to reconstruct the atmospheric record based on snow or ice-core records, we need to understand the processes by which particles and gases reach their final position embedded in glacial ice. These processes include (1) particles and gases being emitted from sources and carried through the atmosphere to the air over the glacier, (2) the constituents being trans-

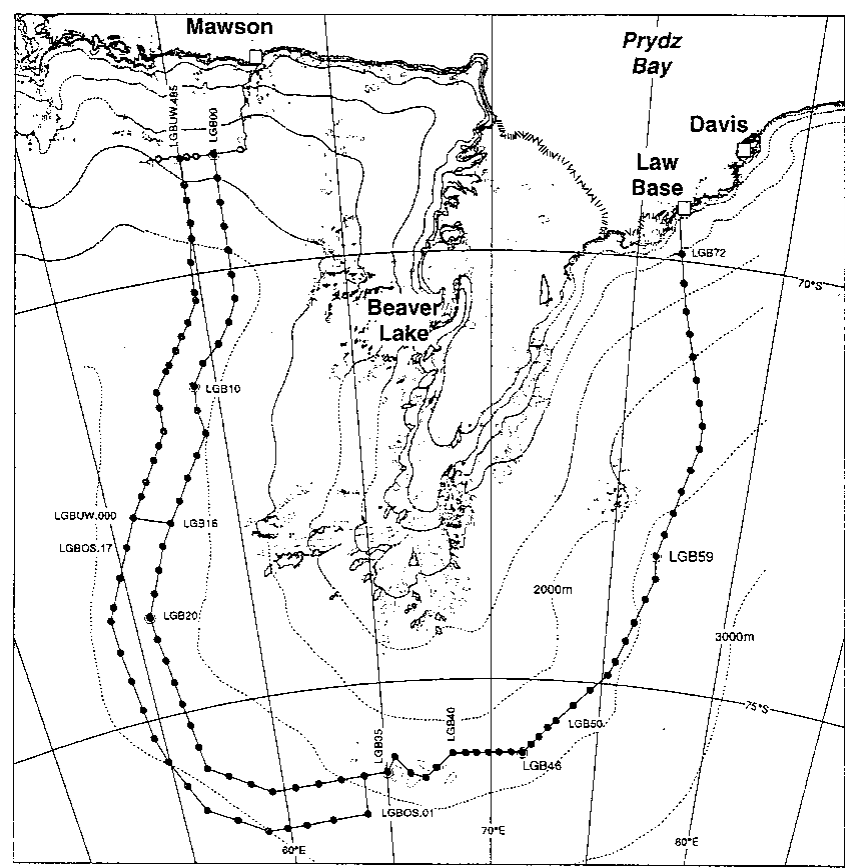

Fig. 1. Map of Antarctica, showing locations mentioned in text.

ported from the atmosphere to the surface of the glacier by a combination of deposition processes, i.e. wet deposition, dry deposition and fog deposition, and (3) post-depositional modification (Davidson and others, 1996). At present, the relationship between the composition of snow and that of the atmosphere, and the processes of air/sea exchange and DMS oxidation are unclear. Therefore, we assume that the MSA record in snow and ice cores reflects the variability of marine DMS emissions in the past. 
To date, MSA data for snow and ice cores in Antarctica are concentrated on the coastal areas and are rather sparse. During the 1992-93 Australian National Antarctic Research Expeditions (ANARE) Lambert Glacier basin (LGB) traverse program, a $2.7 \mathrm{~m}$ snow pit was sampled at station LGB16 (Fig. 1). Based on the analysis of snow-pit samples, this paper focuses on (1) understanding the range and seasonal pattern of MSA and non-sea-salt $\mathrm{SO}_{4}{ }^{2-}$ $\left(\mathrm{nsSSO}_{4}{ }^{2-}\right),(2)$ the effect of volcanoes on the $\mathrm{nssSO}_{4}{ }^{2-}$ record, and (3) the relationship of MSA with sea-ice extent and El Niño-Southern Oscillation (ENSO) events.

\section{SAMPLING SITES AND ANALYTIGAL PROGEDURE}

A $2.7 \mathrm{~m}$ snow pit was excavated at $\operatorname{LGB16}\left(72.8^{\circ} \mathrm{S}, 57.3^{\circ} \mathrm{E}\right)$ in the Lambert Glacier basin, East Antarctica (Fig. 1), on 13 January 1993 (Ren and others, 1998). The sampling site, about $650 \mathrm{~km}$ from the coast, was at approximately $2690 \mathrm{~m}$ a.s.l. The mean snow accumulation was $110 \mathrm{~kg} \mathrm{~m}^{-2} \mathrm{a}^{-1}$ (corresponding to $25.7 \mathrm{~cm} \mathrm{snow}^{-1}$ ), and the $10 \mathrm{~m}$ firn temperature was approximately $-42.9^{\circ} \mathrm{C}$. The prevailing winds at this location are continental in origin, predominantly from the south. The annual wind speed is about $7-8 \mathrm{~m} \mathrm{~s}^{-1}$, which is substantially less than on the coast (about $10-12 \mathrm{~m} \mathrm{~s}^{-1}$ ) (Higham and Craven, 1997). The snow pit was sampled at $3 \mathrm{~cm}$ intervals, which resulted in about eight samples per year. To prevent contamination of the samples, the collector wore pre-cleaned gloves and a mask. After the snow pit was dug, the stratigraphic profile was first recorded, then the leeward wall of the snow pit was scraped clean for sampling. Samples were directly collected into pre-cleaned polyethylene containers for shipment back to Lanzhou, China. Samples were stored frozen at $-15^{\circ} \mathrm{C}$, and were melted immediately before analysis.

Analyses were carried out for anions $\left(\mathrm{Cl}^{-}, \mathrm{NO}_{3}{ }^{-}, \mathrm{SO}_{4}{ }^{2-}\right)$ and cations $\left(\mathrm{Na}^{+}, \mathrm{NH}_{4}^{+}, \mathrm{K}^{+}, \mathrm{Mg}^{2+}, \mathrm{Ca}^{2+}\right)$ prior to this study (Ren and others, 1998). The MSA analyses were carried out using a Dionex Model DX-300 instrument equipped with an AS1l analytical column, an AG1l guard column, anion self-regenerating suppressor and sodium hydroxide eluant (personal communication from S. I. Whitlow, 1996). All measurements were conducted at the Laboratory of Ice Core and Cold Regions Environment, Lanzhou Institute of Glaciology and Geocryology. The analytical uncertainty was estimated at $10 \%$ or less.

For aerosol species, the main deposition processes are considered to be wet deposition, dry deposition and fog deposition (Davidson and others, 1996). Both model and experimental estimates suggest that dry deposition and fog deposition are minor contributors to the annual flux for coastal Antarctica, and the key deposition process is wet deposition (Wolff and others, 1998). Experiments at Summit, Greenland, also suggest that wet deposition is responsible for the bulk of mass deposition of several chemical species onto the ice sheet. For MSA, $\mathrm{SO}_{4}{ }^{2-}$ and $\mathrm{Na}^{+}$, wet deposition accounts for an average of $64 \%$ of total deposition (Davidson and others, 1996). Although no experiments on relative contribution of deposition processes have been carried out in the Lambert Glacier basin, we assume that wet deposition is a dominant process contributing to the annual flux in this region. Therefore, we use the concentrations of sodium, sulphate and MSA in the snow as proxies for local atmospheric concentration of these species in this study.
The sea-ice data were obtained from the U.S. Navy/U.S. National Oceanic and Atmospheric Administration satellite maps of the northern limit of the sea-ice extent. The records of sea-ice extent were compiled by T. H. Jacka. They are available via the internet at http://www.antcrc.utas.edu.au/ $\sim$ jacka/climate.html and include the distance from the South Pole to the ice edge at every $10^{\circ}$ of longitude, with one map for each month from 1973 through 1997. The sea-ice area for each month was determined by calculating the area for each $10^{\circ}$ wedge, summing them and then subtracting the area of the Antarctic continent. The monthly sea-ice area for the South Indian Ocean sector was determined by using the distance to the ice edge from $40^{\circ}$ to $90^{\circ} \mathrm{E}$ longitude.

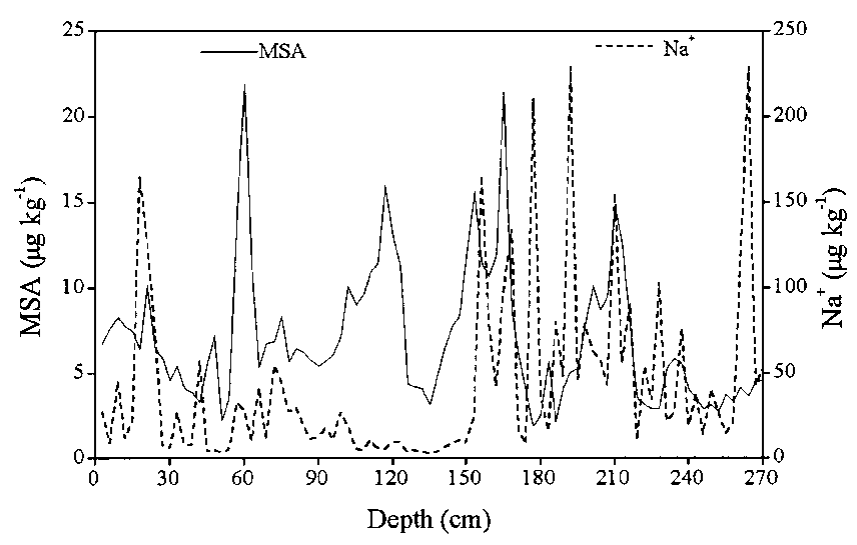

Fig. 2. Concentration of MSA and $\mathrm{Na}^{+}$vs depth for snow-pit samples collected at LGB16.

\section{RESULTS AND DISGUSSION}

\section{Dating}

It is well known that MSA exhibits a consistent and strong seasonal cycle, with maxima in the summer and minima in the winter, in aerosol and surface snow samples from Antarctica (Minikin and others, 1998). However, MSA concentrations from the deeper sections of a Dolleman Island ice core (Mulvaney and others, 1992) demonstrate well-defined seasonal maxima in winter rather than summer, and are out of phase with nssSO ${ }_{4}{ }^{2-}$ concentrations maxima, which suggests that MSA migrates out of the layers of snow with relatively high $\mathrm{SO}_{4}{ }^{2-}$ concentrations and into adjacent layers rich in sea salt. Ice cores from the Dyer Plateau and Gomez Nunatak (Mulvaney and others, 1992), however, have MSA and $\mathrm{nsSSO}_{4}{ }^{2-}$ concentration maxima in summer. A similar pattern is reported for MSA in Antarctic ice cores from Law Dome (Ivey and others, 1986; Curran and others, 1998). The profiles of MSA and $\mathrm{Na}^{+}$do not show a clear relationship in our snow pit (Fig. 2). Generally, MSA and $\mathrm{Na}^{+}$concentration maxima do not coincide, so we assume that post-depositional migration of MSA is negligible. We thus assign MSA maxima to summer periods. Using MSA variations for dating, our snow samples cover the time period 1981-92, which is the same as that assigned by stratigraphic observations (Ren and others, 1998). This suggests that our assumption of summer MSA maxima is valid for this snow pit. 

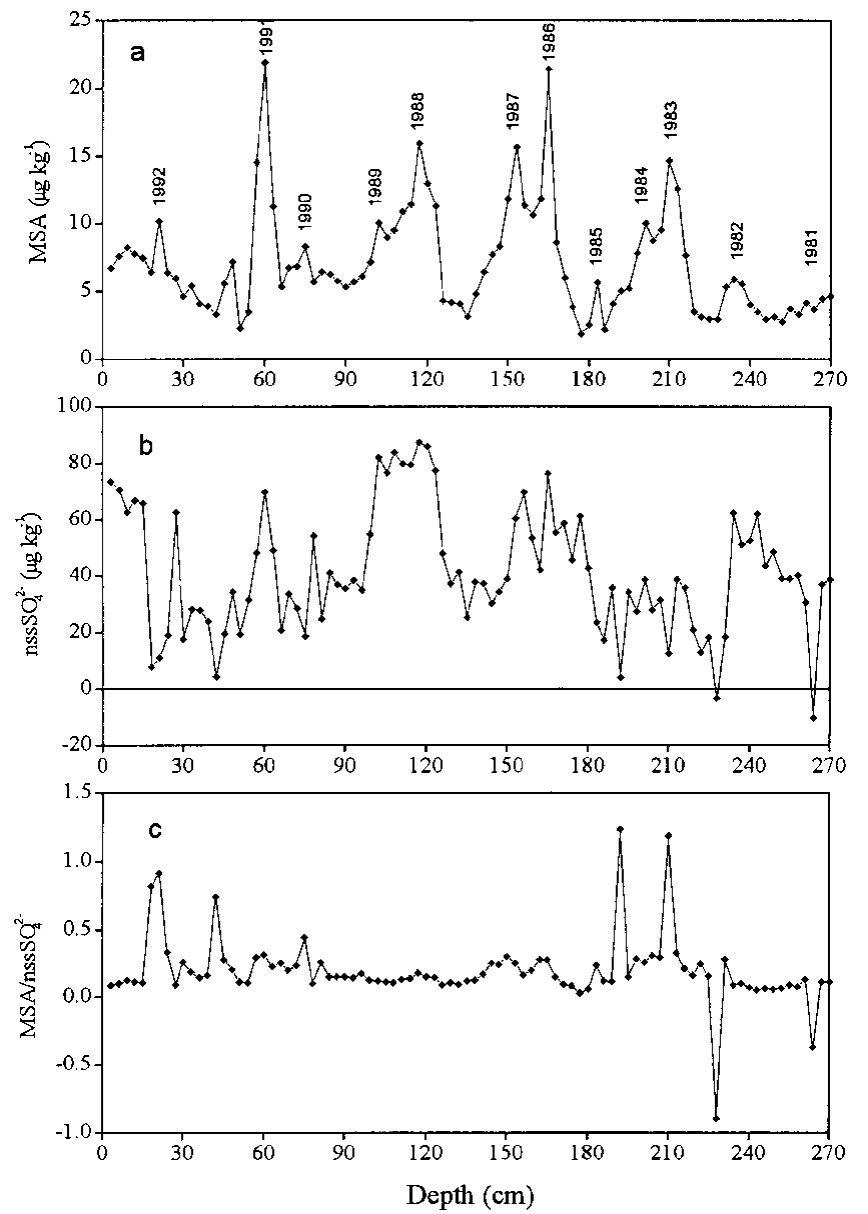

Fig. 3. Profiles of (a) MSA and (b) $\mathrm{nsSSO}_{4}{ }^{2-}$, and (c) their mass ratio with depth in the snow pit at LGB16.

\section{$\mathrm{nsSSO}_{4}{ }^{2-}$ calculations}

Using sodium concentration as an indication of sea-salt content, the $\mathrm{nssSO}_{4}{ }^{2-}$ concentrations are commonly calculated by

$$
\mathrm{nssSO}_{4}{ }^{2-}=\text { total } \mathrm{SO}_{4}{ }^{2-}-0.2517 \mathrm{Na}^{+} \text {. }
$$

Negative nss $\mathrm{SO}_{4}{ }^{2-}$ concentrations were first reported by Gjessing (1984) for firn-core samples from the Riiser-Larsen Ice Shelf and by Wagenbach and others (1988) at Neumayer for winter aerosol samples. This phenomenon was also observed in firn cores from the Antarctic Peninsula (Mulvaney and others, 1992) and the Filchner-Ronne Ice Shelf (Minikin and others, 1994), and in aerosol and fresh-snow samples from Neumayer, Halley and Dumont d'Urville (Wagenbach and others, 1998). The negative $\mathrm{nssSO}_{4}{ }^{2-}$ concentration may be due to the occurrence of significant sulfate depletion in the aerosol compared to the sea-water ratio, due to the low temperature as a result of $\mathrm{Na}_{2} \mathrm{SO}_{4} \cdot 10 \mathrm{H}_{2} \mathrm{O}$ precipitation during the freezing of sea water (Wagenbach and others, 1998). It is noteworthy that the calculated negative $\mathrm{nsSSO}_{4}{ }^{2}$ values in snow and aerosol are common in the coastal regions during the winter months. We assume no fractionation of sea-salt $\mathrm{Na}^{+}$and $\mathrm{SO}_{4}{ }^{2-}$ during transport to the ice sheet, because no year-round aerosol samples allow us to estimate the fractionated sulfate/sodium ratio of aerosol in the study area.

Negative values of $\mathrm{nsSSO}_{4}{ }^{2-}$ were calculated for depths of $228 \mathrm{~cm}\left(-3.8 \mu \mathrm{g} \mathrm{kg}^{-1}\right)$ and $264 \mathrm{~cm}\left(-10.6 \mu \mathrm{g} \mathrm{kg}^{-1}\right)$ (Fig. 3). This small number of negative $\mathrm{nsSOO}_{4}{ }^{2-}$ values suggests that sulfate fractionation is not large during sea-salt aerosol production and transport to this site.

\section{MSA and $\mathrm{nssSO}_{4}{ }^{2-}$ profiles}

Concentrations of MSA and $\mathrm{nsSOO}_{4}{ }^{2-}$ and their mass ratio vs depth are shown in Figure 3. The seasonal pattern of MSA is clearer than that of $\mathrm{nsSSO}_{4}{ }^{2-}$, which attains maxima presumably during summer as a result of elevated marine biogenic production (Saigne and Legrand, 1987; Legrand and FenietSaigne, 1991; Pasteur and others, 1995). The concentration of MSA ranges from 1.9 to $22.0 \mu \mathrm{g} \mathrm{kg}^{-1}$, with a mean of $7.0 \pm 4.0 \mu \mathrm{g} \mathrm{kg}^{-1}$, while the total sulfate ranges from 18.9 to $114.5 \mu \mathrm{g} \mathrm{kg}^{-1}$ with a mean of $52.6 \pm 21.4 \mu \mathrm{g} \mathrm{kg}^{-1}$. On average, MSA accounts for about $12 \%$ of total sulfur deposition $\left(\mathrm{MSA}+\mathrm{SO}_{4}{ }^{2-}\right)$ and thus is a relatively minor contributor. The mean value and the range of MSA concentrations are in good agreement with those measured at Law Dome, Antarctica (Ivey and others, 1986), at South Pole in snow for 1922-80 (Legrand and Feniet-Saigne, 1991) and in snow over the International Trans-Antarctic Expedition route where MSA concentrations vary from 1.0 to $28.7 \mu \mathrm{g} \mathrm{kg}^{-1}$ (Qin, 1995). The mean MSA concentrations at LGB16 are approximately onehalf of those in snow at the Filchner-Ronne Ice Shelf (Minikin and others, 1994) and are much lower than those recorded in snow at Dolleman Island (Mulvaney and others, 1992), but a little higher than those in snow/ice at Dome $\mathrm{C}$ and Vostok during the Holocene (Legrand and others, 1991). The $\mathrm{nsSSO}_{4}{ }^{2-}$ varies from 0 to $87.6 \mu \mathrm{g} \mathrm{kg}^{-1}$, with a mean of $42.5 \pm 20.7$ (ignoring the two negative values), and on average explains about $80 \%$ of the total sulfate in the snow pit. At South Pole, $\mathrm{nssSO}_{4}{ }^{2-}$ accounts for $>90 \%$ of the total sulfate (Whitlow and others, 1992) whereas it accounts for about $70 \%$ at Dolleman Island and Gomez Nunatak (Mulvaney and others, 1992). This suggests that $\mathrm{nssSO}_{4}{ }^{2-}$ becomes more dominant towards the interior of the Antarctic continent.

The mean mass ratio of MSA to $\mathrm{nsSO}_{4}{ }^{2-}$ is 0.176 , which is very close to the ratio of 0.18 observed at South Pole (Dibb and Whitlow, 1996) but much higher than that observed (0.06-0.07) in the low to mid-marine atmosphere (Saltzman and others, 1986). The ratio of $\mathrm{MSA}$ to $\mathrm{nssSO}_{4}{ }^{2-}$ in snow for the period 1981-92 is more stable than the MSA record, which suggests that there has been little change in the location and relative magnitudes of the sources of MSA and $\mathrm{nssSO}_{4}{ }^{2-}$ transported to this location during 1981-92.

\section{Volcanoes and the nssSO ${ }_{4}{ }^{2-}$ record}

Explosive volcanic eruptions inject a large quantity of dust and gases (including $\mathrm{SO}_{2}$ ) into the atmosphere and often into the stratosphere. This $\mathrm{SO}_{2}$ is oxidized to form sulfuric acid aerosol particles, which can be spread globally via atmospheric circulation to then be recorded in polar snow as high nssSO ${ }_{4}{ }^{2-}$ concentrations and high acidity (Legrand and Delmas, 1987; Dibb and Whitlow, 1996; Cole-Dai and others, 1997b).

In the period 1981-92, there were three eruptions that likely influenced the $\mathrm{SO}_{2}$ content of the atmosphere over Antarctica. The eruption of El Chichon $\left(17.3^{\circ} \mathrm{N}, 93.2^{\circ} \mathrm{W}\right)$ in April 1982 loaded $7 \pm 2 \mathrm{Mt}$ of $\mathrm{SO}_{2}$ (Bluth and others, 1992) to levels as high as $20-26 \mathrm{~km}$ into the atmosphere (Seftor and others, 1997). The 1991 Pinatubo eruption $\left(15.14^{\circ} \mathrm{N}\right.$, $\left.120.35^{\circ} \mathrm{E}\right)$ in the Philippines emitted an estimated $18 \pm 2 \mathrm{Mt}$ of $\mathrm{SO}_{2}$ (Krueger and others, 1995), which was oxidized to $28 \mathrm{Mt}$ of aerosol sulfuric acid in the stratosphere 
within the following two months (Cole-Dai and others, 1997b). The August 1991 eruption of Mount Hudson $\left(45.92^{\circ} \mathrm{S}, 73.0^{\circ} \mathrm{W}\right)$ in Chile was much smaller, emitting an estimated 1.5 Mt of $\mathrm{SO}_{2}$ (Doiron and others, 1991). But the Hudson eruption was much closer to Antarctica than the Pinatubo eruption. Thus, the Hudson volcanic aerosol began to appear over South Pole in September 1991 and disappeared by the end of January 1992, whereas the Pinatubo volcanic aerosol began to spread poleward in late August or early September 1991 and covered the entire globe by mid-1992 (Cacciani and others, 1993; Hitchman and others, 1995).

It typically takes 1 or 2 years for stratospheric volcanic sulfate to be transported from the low latitudes to Antarctica (Cole-Dai and others, 1997a). During the 2 years following the $1982 \mathrm{El}$ Chichon eruption, $\mathrm{nssSO}_{4}{ }^{2-}$ in snow at LGB16 was below the mean nssSO $_{4}{ }^{2-}$ concentration in this snow pit. This suggests that the El Chichon signal was not detected in snow at this site. Increased concentration of $\mathrm{nssSO}_{4}{ }^{2-}$ in snow from late 1991 and after mid-1992 would be expected, due to the contributions of the Hudson and Pinatubo eruptions, respectively (Cole-Dai and others, 1997b). The $\mathrm{nsSO}_{4}{ }^{2-}$ concentration in 1992 snow at LGB16 is elevated compared to the mean concentration, but similar to that observed in 1988-89, when no large volcanoes erupted. Thus, we believe that our nss $\mathrm{SO}_{4}{ }^{2-}$ record shows no significant perturbation due to the Hudson eruption. We cannot make a definitive conclusion regarding the effect of the Pinatubo eruption on our $\mathrm{nssSO}_{4}{ }^{2-}$ record, since it extends only to 1992.

The volcanic eruptions of El Chichon, Hudson and Pinatubo are recorded in nssSO ${ }_{4}{ }^{2-}$ in the snow at South Pole (Legrand and Feniet-Saigne, 1991; Dibb and Whitlow, 1996; Cole-Dai and others, 1997b). Moreover, Cole-Dai and others (1997b) differentiated the Pinatubo eruption layer from the Hudson eruption layer using tephra particles as a tracer. However, the $1982 \mathrm{El}$ Chichon nss $\mathrm{SO}_{4}{ }^{2-}$ signal was not detected in the Siple and Dyer ice cores (Cole-Dai and others, 1997a). Similar results were reported for the Dolleman ice core (Peel and Mulvaney, 1992) and a James Ross Island firn core (Aristarain and others, 1982). Legrand and Delmas (1987) reported that the Agung volcanic $\mathrm{SO}_{4}{ }^{2-}$ signal is better defined in central Antarctic areas (Vostok, Dome C and South Pole) than in more coastal areas (D80), although the volcanic $\mathrm{SO}_{4}{ }^{2-}$ signal is smoothed at Siple station. It seems that volcanic $\mathrm{SO}_{4}{ }^{2-}$ signals are clearer in snow at low-accumulation inland sites than at high-accumulation sites near the coast such as LGB16.

\section{ENSO, sea-ice extent and MSA record}

MSA and $\mathrm{SO}_{2}$ (which is oxidized to $\mathrm{nssSO}_{4}{ }^{2-}$ in the atmosphere) are two major oxidation products (Hatakeyama and others, 1985) of DMS, a sulfur gas derived from the metabolism of some types of marine phytoplankton in the ocean (Welch and others, 1993). Unlike nssSO ${ }_{4}{ }^{2-}, \mathrm{MSA}$ is exclusively derived from the oxidation of DMS. Thus, MSA in ice cores has been used as a proxy of biological production in the Southern Ocean (Saigne and Legrand, 1987). Welch and others (1993) found a positive relationship between MSA in a snow pit on Newall Glacier and the sea-ice area of the Ross Sea and the Southern Ocean. High MSA concentrations in a South Pole firn core are closely correlated to major ENSO events (Legrand and Feniet-Saigne, 1991).

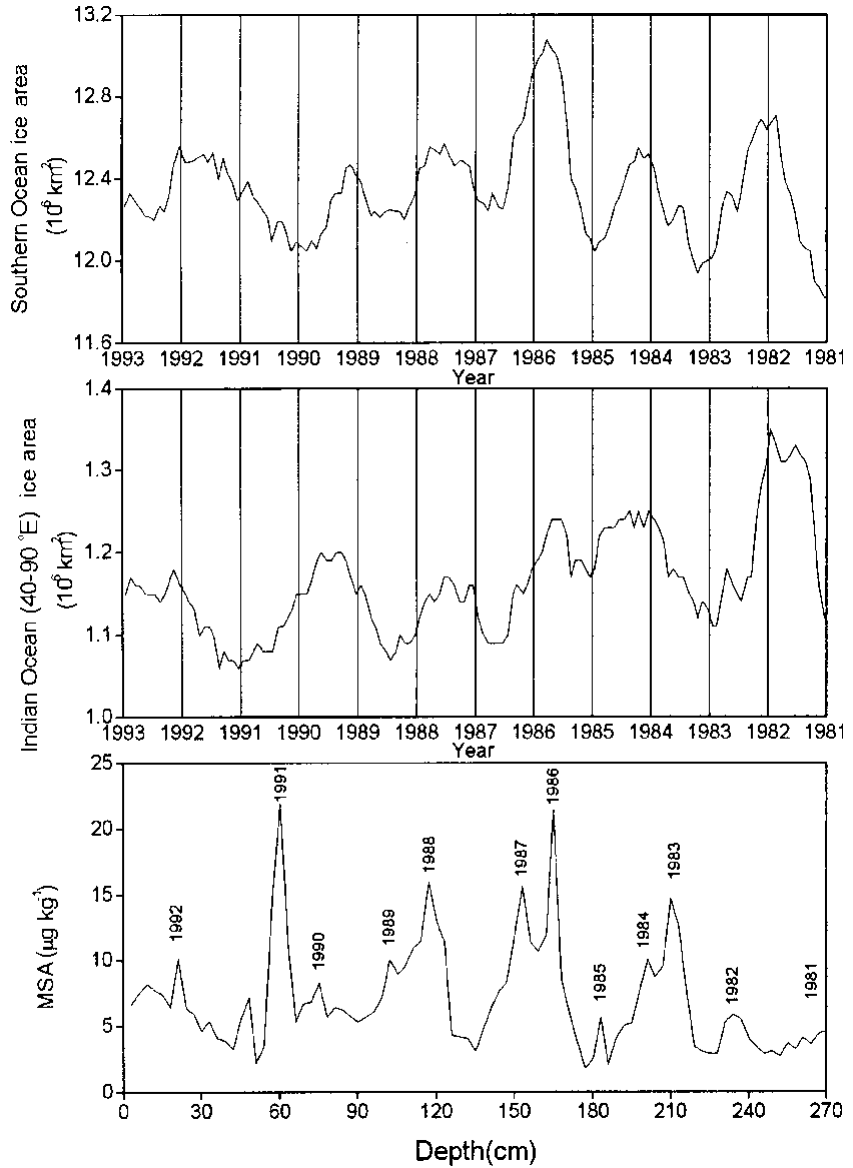

Fig. 4. MSA concentrations vs depth, and sea-ice areas for the Southern Ocean and the South Indian Ocean sector (40$90^{\circ} \mathrm{E}$ ) vs time. Since the amplitude of the seasonal change in sea ice is much larger than the year-to-year variability, records of sea-ice area were smoothed using a 12 month running mean to compare them visually to the MSA record.

However, the MSA records in ice cores drilled on Dolleman Island on the east coast of the Antarctic Peninsula show a small and significant anticorrelation with sea-ice duration recorded at Scotia Bay, Laurie Island in the South Orkney Islands, and no significant link with El Niño events (Pasteur and others, 1995). We have compared our snow-pit MSA record with the sea-ice area record for the Southern Ocean and the South Indian Ocean sector between $40^{\circ}$ and $90^{\circ} \mathrm{E}$ (Fig. 4). There is no relationship between our mean annual MSA concentrations and the mean annual sea-ice areas for the Southern Ocean $(r=-0.08)$, but there is significant anticorrelation $(r=-0.67$, confidence level $95 \%)$ between mean annual MSA concentrations and mean annual sea-ice areas for the South Indian Ocean sector between $40^{\circ}$ and $90^{\circ} \mathrm{E}$. Over the 1981-95 time period, ENSO events occurred in 1982-83, 1986-87-88 and 1990-95, of which the 1982-83 event is the strongest (Assel, 1998), while the 1990-95 event is the longest on record during this century (Trenberth and Hoar, 1996). According to the multivariate ENSO index, ENSO in late 1982 is stronger than in 1991, which is stronger than in 1986. MSA concentration in snow shows no clear relationship with the timing and strength of the ENSO events. The anticorrelation of MSA concentration and sea-ice extent in the South Indian Ocean sector suggests that low sea-ice cover may favor biological production of DMS, hence MSA, in this region. 


\section{GONCLUSION}

This study has shown that MSA and $\mathrm{nsSSO}_{4}{ }^{2-}$ concentrations pose distinct variations in snow from a snow pit in the Lambert Glacier basin. MSA shows clearer seasonal variations than $\mathrm{nss}_{\mathrm{SO}}{ }^{2-}$. The range of MSA concentration is similar to that reported for other regions in Antarctica, except at Dolleman Island, which is thought to be close to a region of high biological productivity. $\mathrm{nsSSO}_{4}{ }^{2-}$ in snow at this site does not record the El Chichon and Hudson eruption signals which are recorded in the snow at South Pole. This suggests either that the atmospheric circulation does not favor the transport of volcanic $\mathrm{SO}_{4}{ }^{2-}$ from the stratosphere to this site, or that high accumulation rates may dilute the volcanic $\mathrm{SO}_{4}{ }^{2-}$ signal. We observed a significant anticorrelation between MSA concentration in snow and sea-ice area for the South Indian Ocean sector $\left(40-90^{\circ} \mathrm{E}\right)$, but no clear relationship between MSA and ENSO events. This suggests that low sea-ice cover favors biological production of DMS in this region.

\section{ACKNOWLEDGEMENTS}

We thank the Australia Antarctic Science Foundation and the Australian Antarctic Division for providing support for one of the authors, Ren Jiawen, to join the ANARE LGB traverse expedition. We also thank T. H. Jacka for providing the sea-ice records and P. Sedwick and an anonymous reviewer for their useful suggestions. This research was supported by the Chinese Academy of Sciences (KZ951-Al205), the State Commission of Sciences and Technology of China (98-927-01-05 and 98-927-01-07) and the National Natural Science Foundation of China (49271022).

\section{REFERENCES}

Aristarain, A. J., R. J. Delmas and M. Briat. 1982. Snow chemistry onJames Ross Island (Antarctic Peninsula). 7. Geophys. Res., 87(C13), 11,004-11,012.

Assel, R. A. 1998. The 1997 ENSO event and implication for North American Laurentian Great Lakes winter severity and ice cover. Geophys. Res. Lett., 25(7), 1031-1033.

Bates, T. S., B. K. Lamb, A. Guenther, J. Dignon and R. E. Stoiber. 1992. Sulfur emissions to the atmosphere from natural sources. F. Atmos. Chem., 14(1-4), 315-337.

Bluth, G. J. S., S. D. Doiron, C. C. Schnetzler, A. J. Krueger and L. S. Walter. 1992. Global tracking of the $\mathrm{SO}_{2}$ clouds from the June 1991 Mount Pinatubo eruptions. Geophys. Res. Lett., 19(2), 151-154.

Cacciani, M., P. di Girolamo, A. di Sarra, G. Fiocco and D. Fua. 1993. Volcanic aerosol layers observed by lidar at South Pole, September 1991June 1992. Geophys. Res. Lett., 20(9), 807-810.

Charlson, R. J., J. E. Lovelock, M. O. Andreae and S. G. Warren. 1987. Oceanic phytoplankton, atmospheric sulphur, cloud albedo and climate. Nature, 326(6114), 655-661.

Cole-Dai, J., E. Mosley-Thompson and L. G. Thompson. 1997a. Annually resolved Southern Hemisphere volcanic history from two Antarctic ice cores. F. Geophys. Res., 102(D14), 16,761-16,771.

Cole-Dai, J., E. Mosley-Thompson and L. G. Thompson. 1997b. Quantifying the Pinatubo volcanic signal in south polar snow. Geophys. Res. Lett., 24(21), 2679-2682.

Gurran, M. A. J., T. D. van Ommen and V. Morgan. 1998. Seasonal characteristics of the major ions in the high-accumulation Dome Summit South ice core, Law Dome, Antarctica. Ann. Glaciol., 27, 385-390.

Davidson, C. I., M. H. Bergin and H. D. Kuhns. 1996. The deposition of particles and gases to ice sheets. In Wolff, E. W. and R. C. Bales, eds. Chemical exchange between the atmosphere and polar snow. Berlin, etc., Springer-Verlag, 275-306. (NATO ASI Series I: Global Environmental Change 43.)

Dibb, J. E. and S. Whitlow. 1996. Recent climatic anomalies and their impact on snow chemistry at South Pole, 1987-1994. Geophys. Res. Lett.,
$23(10), 1115-1118$.

Doiron, S. D., G. J. S. Bluth, C. C. Schnetzler, A. J. Krueger and L. S. Walter. 1991. Transport of Cerro Hudson $\mathrm{SO}_{2}$ clouds. EOS, $72(45), 489$.

Gjessing, Y. 1984. Marine and non-marine composition of the chemical composition of the snow at the Riiser-Larsen Ice Shelf in Antarctica. Atmos. Environ., 18(4), 825-830.

Hatakeyama, S., K. Isumi and H. Akimoto. 1985. Yield of $\mathrm{SO}_{2}$ and formation of aerosol in the photo-oxidation of DMS under atmospheric conditions. Atmos. Environ., 19(1), 135-141.

Higham, M. and M. Craven. 1997. Surface mass balance and snow surface properties from the Lambert Glacier basin traverses 1990-94. Hobart, Tasmania, Cooperative Research Centre for the Antarctic and Southern Ocean Environment. (Research Report 9.)

Hitchman, M. H., M. McKay and C. R. Trepte. 1995. A climatology of stratospheric aerosol. F. Geophys. Res., 99 (D10), 20,698-20,700.

Ivey, J. P., D. M. Davies, V. Morgan and G. P. Ayers. 1986. Methanesulphonate in Antarctic ice. Tellus, 38B(5), 375-379.

Krueger, A. J. and 6 others. 1995. Volcanic sulfur dioxide measurements from the total ozone mapping spectrometer instruments. 7. Geophys. Res., 100 (D7), 14,057-14,076.

Legrand, M. R. and R. J. Delmas. 1987. A 220-year continuous record of volcanic $\mathrm{H}_{2} \mathrm{SO}_{4}$ in the Antarctic ice sheet. Nature, 327(6124), 671-676.

Legrand, M. and C. Feniet-Saigne. 1991. Methanesulfonic acid in south polar snow layers: a record of strong El Niño? Geophys. Res. Lett., 18(2), 187-190.

Legrand, M., C. Feniet-Saigne, E. S. Saltzman, C. Germain, N. I. Barkov and V. N. Petrov. 1991. Ice-core record of oceanic emissions of dimethylsulphide during the last climate cycle. Nature, 350(6314), 144-146.

Minikin, A., D. Wagenbach, W. Graf and J. Kipfstuhl. 1994. Spatial and seasonal variations of the snow chemistry at the central Filchner-Ronne Ice Shelf, Antarctica. Ann. Glaciol., 20, 283-290.

Minikin, A. and 7 others. 1998. Sulfur-containing species (sulfate and methanesulfonate) in coastal Antarctic aerosol and precipitation. 7. Geophys. Res., 103(D9), 10,975-10,990.

Mulvaney, R., E. C. Pasteur, D. A. Peel, E. S. Saltzman and P.-Y. Whung. 1992. The ratio of MSA to non-sea-salt sulphate in Antarctic Peninsula ice cores. Tellus, 44B (4), 295-303.

Pasteur, E. C., R. Mulvaney, D. A. Peel, E. S. Saltzman and P.-Y. Whung. 1995. A 340 year record of biogenic sulphur from the Weddell Sea area, Antarctica. Ann. Glaciol., 21, 169-174.

Peel, D. A. and R. Mulvaney. 1992. Time-trends in the pattern of ocean-atmosphere exchange in an ice core from the Weddell Sea sector of Antarctica. Tellus, 44B (4), 430-442.

Qin Dahe. 1995. The physical process and modern climate and environment record of surface snow over Antarctic ice sheet. Beijing, Scientific Press.

Ren Jiawen, Sun Junying and Qin Dahe. 1998. [Preliminary result of glaciochemistry study on a firn core and a snowpit in west part of Lambert Glacier basin, East Antarctica.] Annu. Rep. Lab. Ice Core Cold Reg. Environ., 4, 34-41. [In Chinese with English summary.]

Saigne, C. and M. Legrand. 1987. Measurements of methanesulphonic acid in Antarctic ice. Nature, 330(6145), 240-242.

Saltzman, E. S. 1995. Ocean/atmosphere cycling of dimethylsulfide. In Delmas, R. J., ed. Ice core studies of global biogeochemical cycles. Berlin, etc., Springer-Verlag, 65-90. (NATO ASI Series I: Global Environmental Change 30.)

Saltzman, E. S., D. L. Savoie, J. M. Prospero and R. G. Zika. 1986. Methanesulphonic acid and non-sea-salt sulphate in Pacific air: regional and seasonal variations. F. Atmos. Chem., 4, 227-240.

Seftor, C. J. and 7 others. 1997. Detection of volcanic ash clouds for Nimbus 7 total ozone mapping spectrometer. f. Geophys. Res., 102(D14), 16,749-16,759.

Trenberth, K. E. and T. J. Hoar. 1996. The 1990-1995 El Niño-Southern Oscillation event: longest on record. Geophys. Res. Lett., 23(1), 57-60.

Wagenbach, D., U. Görlach, K. Moser and K. O. Münnich. 1988. Coastal Antarctic aerosol: the seasonal pattern of its chemical composition. Tellus, 40B(5), 426-436.

Wagenbach, D. and 7 others. 1998. Sea-salt aerosol in coastal Antarctic regions. F. Geophys. Res., 103(D9), 10,961-10,974.

Welch, K. A., P. A. Mayewski and S. I. Whitlow. 1993. Methanesulfonic acid in coastal Antarctic snow related to sea ice extent. Geophys. Res. Lett., $20(6), 443-446$.

Whitlow, S., P. A. Mayewski and J. E. Dibb. 1992. A comparison of major chemical species seasonal concentration and accumulation at the South Pole and Summit, Greenland. Atmos. Environ., 26A(11), 2045-2054.

Wolff, E. W., J. S. Hall, R. Mulvaney and E. C. Pasteur. 1998. Relationship between chemistry of air, fresh snow and firn cores for aerosol species in coastal Antarctica. 7. Geophys. Res., 103 (D9), 11,057-11,070. 